\title{
PHOTOGRAPHY CLICHÉS: ON BAUDELAIRE'S MEDIA AESTHETICS AND THE MECHANICAL ARTS
}

\section{Marit Grøtta}

\begin{abstract}
The aim of this article is two-folded. First, I wish to situate Baudelaire in the midst of $19^{\text {th }}$-century media, bring attention to the way he explored the new media of his day, and suggest that he developed his own media aesthetics. Second, I wish to examine Baudelaire's relation to photography more specifically, emphasizing his love of commonplaces and clichés. I begin by contextualizing Baudelaire's notorious attack on photography in the Salon de 1859 and then examine three poems in light of the photographic culture of Baudelaire's day. Central here is the experiment on the notion of identity that was carried out with the spread of portrait photography: the notation of a unique identity was undermined, processes of multiplication were explored, and the poetic discourse of the "soul" was radically changed.
\end{abstract}

\section{KEYWORDS}

Charles Baudelaire, Media aesthetics, Poetry, Photography, Clichés, Dispositives, Play

The relation between media technology and art in the $19^{\text {th }}$ century has often been seen as antithetical. As an alleged "pure" poet opposed to the mechanical arts and progress, Charles Baudelaire (1821-1867) has been used as a key example of a reactionary attitude to technology. He has embodied the hostility towards photography, newspapers, and capitalist forces that was widespread among poets and artists in the $19^{\text {th }}$ century. Also in Walter Benjamin's influential writings on the urban and social transformation that took place in Paris with the advent of a capitalist culture, Baudelaire plays a key role and is portrayed as a poet who battled the new media. However, 150 years after Baudelaire's death and after decades of research on Baudelaire, Benjamin, and the media, this position may be in need of reconsideration. The antithetical model does not capture the dynamic interplay between the arts and $19^{\text {th }}$-century media, nor does it capture the complexity of Baudelaire's position or the sophistication of his poetry. 
It matters how we conceive of these relations today, in an age of advanced media technology and ubiquitous mediation. At stake is the relation between art and technology, between tradition and progress, and not the least the role of the poet in periods of cultural transformation and media change. Looking back at $19^{\text {th }}$ century, we see rise of capitalism and the beginning of the media age that we live in today, and if we do not capture the complexities of this period, we may miss the chance to relate it to our own situation. If we do not understand the early and indeed slow age of reproduction, how can we understand the accelerated media society we live in today?

Thus, we should return once more to Paris in the mid- $19^{\text {th }}$ century, to the time when the city was transformed into a modern capital. As is well known, Baron Haussmann's urban planning gave the city a new structure that allowing for the free circulation of traffic, people and commodities. ${ }^{1}$ However, not only the physical transformations of urban space should be considered; equally important was the rise of the new media and the new visual culture that took form, influencing the citizen's perception and mindset. This is the time when the commercial newspaper triumphed (with lots of advertisements and a solid quantity of fake news), photographs came into circulation (especially the bourgeois genre of portrait photographs), and numerous pre-cinematic devices (such as phenakistiscopes, stereoscopes, and kaleidoscopes) were used as toys by private citizens or made available at public fairs. Indeed, $19^{\text {th }}$-century media culture was thriving, and it included a large variety of media, techniques and genres.

My aim is to situate Baudelaire in the midst of $19^{\text {th }}$-century media culture and take seriously the fact that he lived in a media saturated environment. Even if he despised the commerce of the newspapers and the industry of photography, he was fascinated with the way the new media changed our perception and keenly aware of the rich imagery they offered. Of course Baudelaire did not merely fight against the new media, and he did not simply succumb to their dominant position. Rather, he responded to the influence of the new media culture in his writings and aesthetics. My hypothesis is that Baudelaire explored the perceptual possibilities of the new media in his writings, trying them out as frames of perception and as "interfaces" between man and the world. Combining these features with a solid romantic legacy, he created his own media aesthetics.

Crucial to this hypothesis is the fact that Baudelaire's aesthetic investigations include a large number of arts and media, both from the traditional arts and from popular culture. As a poet and an art critic, he reflected upon painting, sculpture, poetry, the theatre, the 
pantomime, caricature, and drawing (and this is of course not an exhaustive list). His aesthetics could thus be seen as intermedial at its core, and his interest in $19^{\text {th }}$-century media may be considered a prolongation of his interest in the traditional arts. It is also important that Baudelaire was committed to the "art of transposition" and frequently sought to emulate other artists in the medium of writing. Yet, he repeatedly observed the shortcomings of writing when it comes to capturing the aesthetics of another medium: "Set down with the pen, the whole thing seems pale and chill" 2 ; "It is difficult in all conscience for the pen to translate this" 3 ; "[It is] very difficult to note down in shorthand". ${ }^{4}$ Yet his writings are often inspired by other media; by their aesthetics, forms and techniques, as well as the fantasies and imagery they stirred.

My proposition is to use the concept of "dispositive" to describe the workings of the $19^{\text {th }}$-century media. This concept allows us to grasp the interplay between perception and various processes of mediation, and hence the ways the media shape and guide the way the world is seen. The concept has a complex genealogy, but it appears to have emerged in the 1970s in two different contexts: critical cinema theory and Foucault's work on the history of sexuality. ${ }^{5}$ Taking his cue from Foucault, Giorgio Agamben has defined it in the following manner: "literally anything that has in some way the capacity to capture, orient, determine, intercept, model, control, or secure the gestures, behaviors, opinions, or discourses of living beings." 6 His examples are not only prisons and hospitals, but also cell phones, computers, and in a certain sense, language as well. In this manner, Agamben explicitly includes communication technology in the concept of the dispositive, and even seems to give it a privileged role

Seeing $19^{\text {th }}$-century media as dispositives, I would like to suggest that Baudelaire played with the media dispositives of his day, trying them out as frames of perception and ways of experiencing the world. ${ }^{7}$ This approach is inspired both by critical theory and by recent work in media aesthetics and the wider aesthetic field, exploring questions of intermediality and remediation. The concept of intermediality implies that the various media persistently interact with one another; they observe, "think" and respond to one another. ${ }^{8}$ A more specific concept is remediation, which describes the ways in which the conventions of one medium are paraphrased or reused in another medium. 9

I have already put forward these views in my book Baudelaire's Media Aesthetics: The Gaze of the Flâneur and $19^{\text {th }}$-Century Media, with chapters on newspapers, photography, pre-cinematic devices, 
and (mechanical) toys. ${ }^{10}$ In this article I wish to develop on Baudelaire's relation to photography, emphasizing the experiment on the notion of identity that was carried out with the spread of portrait photography. As photographic portraits came into circulation, the idea of a unique identity was undermined, processes of multiplication were explored, and the poetic discourse of the "soul" radically changed. Combined with a romantic interest in dreams and ghosts, $19^{\text {th }}$-century photography offered a rich imagery and abundant possibilities for poetic speculation.

My starting point is Baudelaire's notorious attack on photography in the Salon de 1859, in the section entitled "The modern public and photography." My aim is to situate this attack in a broader context and to show how the topics adressed in this essay are treated by him poetically. Even if Baudelaire' media aesthetics probably finds its most significant expression in his prose poems and essays on modern life, also poems in The Flowers of Evil (Les Fleurs du mal, 1857/1861) may gain by being seen in such a light, especially "Dream of a curious man" and "The seven old of men." In addition I discuss one of his prose poems, "The Generous Gambler.” The last part of the article discusses the theoretical framework I have used and the way it is, after all, indebted to Benjamin.

\section{BAUDELAIRE'S ATTACK ON PHOTOGRAPHY}

In 1859, Baudelaire's was commissioned to write a review of the annual art exhibition in Paris arranged by l'Académie des BeauxArts. His Salon de 1859 was published as a series of letters in the Revue Français, and in the version we read today, each section corresponds to a letter. The critique of photography appeared in the second section entitled "The modern public and photography." However, also the first section is worthy of consideration. There, under the heading "The modern artist," Baudelaire took issue with the paintings exhibited at the arts exhibition. He criticized the modern generation of painters for the way they excelled in banalities, and he described the modern painters as "spoilt children," basking themselves in the glory of previous master painters (such as the romantic painter Delacroix). He added: "Do not be surprised therefore, if banality in the painter has engendered commonplaces [le lieu commun] in the writer. In any case, you will lose nothing by that, for is there anything (and I am delighted to note that you agree with me in this), anything more charming, more productive, more positively exciting, than the commonplace?"11

This nonchalant comment is interesting because is testifies to Baudelaire's love of commonplaces and indicates how they may 
travel from one medium to another. Indeed, commonplaces belong to the arts of reproduction; they are repeated and spread by the crowd, and they are part of the popular culture for which Baudelaire had a soft spot. We should therefore take Baudelaire seriously and not be surprised if his writings have accommodated a number of commonplaces and clichés. As many of Baudelaire's readers have noted, his prose poems use commonplaces from ordinary language, and as Jonathan Culler has shown, the poems in The Flowers of Evil reproduce numerous poetic clichés that had been worn out by his romantic predecessors. For instance, the opening words of "Correspondences": "Nature is a temple," is such a romantic cliché. 12 Thus, when we start reading the second section on photography, we should keep in mind Baudelaire's love of commonplaces and expect that the commonplaces of photography may have translated into his poetry. In fact, the word cliché - which originally referred to the photographic negatives - began to be used as a synonym for commonplace [lieu commun] in French shortly after - in the 1860s.

Why, then, did Baudelaire find it necessary to denounce photography in 1859, twenty years after the presentation of photographic technology at l'Académie des sciences? First and foremost because this year, it threatened to impede on the domain of art. At the Universal Exhibition in London four years earlier, it had been presented as an industrial art, and now it was partly included at the honorable art exhibition of l'Académie des Beaux-Arts, although as a separate exhibition adjoining the official exhibition of paintings. The status and rank of photography was already a debated issue, and Baudelaire must have seen the time ripe to state his opinions on the topic.

Second, photography started to become an important part of $19^{\text {th }}$-century popular culture. In the late 1850 s, its greatest success was in the portrait industry, and a large number of bourgeois clients had their picture taken with solemn faces and stiff postures. Whereas the early technique of daguerreotypes had been based on costly individual prints on silver plates, new techniques with negatives and paper prints were developed during the 1850s, making portrait photograph available to a wider group. A year before Baudelaire wrote his review, a new format had triumphed in the portrait industry: the carte-de-visite, and with this neat and inexpensive format, photographic portraits truly came into circulation.

Third, in the recent years there had been several heated debates in poetic circles about the value of photography, technology and progress. The year of the Universal Exhibition in London, the 
writer and photographer Maxime du Camp published a collection of poems that welcomed progress and industry, Chants modernes (Modern songs, 1855). In his preface he greeted a truly modern poetry celebrating electricity, steam engines and photography. ${ }^{13}$ This unreserved and uncritical appraisal of modern technology was not welcomed by Baudelaire and his associates, and in "The modern public and photography," Baudelaire took issue with his position. The same year, he published a poem that was dedicated to Maxime du Camp ("Voyage," 1859), but only to ironically retort his naive belief in progress. The poem was included in the second edition of The Flowers of Evil (1861), where it served as the closing poem.

Furthermore, in 1859, the term "daguerreotype" had become a loaded word in the quarrel between the idealist and realist camps. The poet Champfleury belonged to the realist camp and asserted that paintings should be "daguerreotypes" of everyday life. The idealist camp, on the other hand, accused the realist painters (and writers) of being mere "daguerreotypeurs," that is, imitators - and even machines. In his manifest on realism, Le Réalisme (1857), Champfleury observed that this kind of "insult" was in vogue. ${ }^{14}$ It was published the same year as The Flowers of Evil, which was accused of - and put to trial for - vulgar realism.

It is within this context - the quarrels about art and technology, about tradition and modernity - that Baudelaire's attack on photography should be situated. When he was commissioned to give a review of the annual art exhibition, he launched an attack against an industry that recently had started to endanger the domain of art. His point of departure was the art of painting, and his concern was the decline in the public's sensitivity to imaginative art. As is well known, Baudelaire praised the imagination; he was committed to Romantic painting and admired the lively colors of Delacroix. By comparison, photography was merely a mechanical art reproducing its objects identically. Baudelaire therefore described it as a new industry that had no artistic potential.15

It is significant that Baudelaire specifically targets the public in his heading "The modern public and photography"; He takes issue not merely with photographic technology, but with the way the public responded to it. His regret was that the public seemed no longer able to appreciate true and beautiful art, but preferred petty, vulgar images. Thus, Baudelaire's aesthetic preferences differed considerably from those of the masses: Where he saw images as an inspiration for the imagination, the public was more fascinated with their verisimilitude, and the technique of photography obviously catered to this particular preference. Against this uncritical attitude, 
Baudelaire asserted that photography should be granted a rather restricted role. It should be considered the servant of the arts and sciences, and humbly assume the same role as the printing press. ${ }^{16}$

With this salon, Baudelaire thus countered techno-optimists such as Du Camp as well as the realist camp in art, such as Champfleury. Yet this does not mean that Baudelaire turned his back on photography as such. Instead I will claim that Baudelaire played with the dispositive of photography in his writings, thus offering a much more sophisticated response to the new industry than the one suggested by Du Camp. Certainly, Baudelaire did not embrace the mechanical arts, but he combined their features with a romantic poetics, thus creating an aesthetics that was deeply ambiguous. The outcome is what we know as Baudelaire's modernity, yet in many cases we may also speak about Baudelaire's media aesthetics.

It should be recalled that it was in this period that Baudelaire learned to know the work of Constantin Guys and wrote the wellknown essay in which he celebrated Guys as the painter of modern life (Le Peintre de la vie moderne), even if it was not published before 1863. Despite the fact that Guys was a "reproduction artist" publishing his sketches in British newspapers, Baudelaire saw him as a painter using his artistic imagination in the making of the sketches. Guys thus combined the best features of painting and the reproduction techniques to convey a vibrant image of modern life. The Painter of Modern Life can thus be seen as one of several attempts from Baudelaire's side to come to terms with the new visual culture and the new techniques of reproduction emerging in the mid- $19^{\text {th }}$ century.

\section{HAVING ONE'S PICTURE TAKEN: PHOTOGRAPHY AND DEATH}

There is one poem that is particularly interesting with respect to Baudelaire's relation to photography: "Dream of a Curious Man" ("Le rêve d'un curieux") a poem that was dedicated to Félix Nadar (Gaspard-Félix Tournachon), the most renowned photographer of Baudelaire's day. It was published in the second edition of The Flowers of Evil, in the section entitled "Death," and the discrete dedication says only "to F.N." Read in light of contemporary debates on the role of photography and the arts of reproduction, it may give a more nuanced picture of Baudelaire's views on photography.

The practical sides of photographic technology were well known to Baudelaire through his friendship and acquaintance with several photographers. He was photographed several times by Nadar in his studio (six of these portraits are known to us today), and he also 
posed for Etienne Carjat and Charles Neyt. Especially important was his friendship with Nadar, even if it was marked by their different views on progress and technology. Indeed, Nadar was on the side of progress, he experimented with photographic techniques (the use of magnesium and electrical lightning) and later became a passionate aéronaute. ${ }^{17}$

At the time, posing for the camera was a new experience, and having one's photograph taken was connected with death and the danger of losing one's soul. Nadar reported that the novelist Honoré de Balzac firmly believed that being photographed removed a layer of his "essential substance," as did also Gérard de Nerval and Theophile Gautier. ${ }^{18}$ Champfleury gave a literal interpretation of this esoteric idea in a story entitled, "The Legend of the Daguerrotypist” (1863). It depicts a photographic session in which the photographer repeatedly commands his client not to move, but has to begin the process over and over again to get it right. In the end, the daguerreotype manages to take a successful portrait, but at this stage, the poor man has disappeared altogether: "Fifty successive attempts had gradually annihilated the body of the model. There was nothing left of M. Balandard, except his voice." 19 The story illustrates the common belief that photographic images are produced at the expense of the model and will eventually lead to his death.

Baudelaire appears to have been inspired by such ideas in his poem the "Dream of a curious man," and the dedication to Nadar is intriguing. Certainly, Nadar was one of the most curious men of his time; he was interested in science, knowledge, and new technologies. However, Nadar's scientific curiosity is in this poem translated into a poetic reverie and mixed up with superstitious ideas and a metaphysical aspiration. In a mysterious way, the poem alludes to the experience of having one's photograph taken, associating the photographic event with death. ${ }^{20}$ Yet the external circumstances of the event are not described. Instead, the poem focuses on the expectations for the event, the illuminating moment itself and its immediate aftermath.

The poem is a sonnet, developing through two quatrains and two tercets. The expectations for death are established in the first quatrain. "I dreamed of dying, in my spirit's heat / Desire and horror mixed, a strange mischance.” 21 In fact, the French original says "I was about to die," not "I dreamed of dying," and thus gives the event more concreteness than the English translation. The second quatrain describes the ticking clock in the form of a time glass: "The more the fatal glass was drained of sand / the more I suffered, 
and I savoured it." Further, the first tercet compares the event to a theatrical play: "I was a child, eager to see a play, / Hating the curtain standing in the way". Indeed, the staged character of the photo session and the cloth covering the camera and the upper body of the photographer may have given associations to a theatrical play. Finally, the second tercet describes the moment of truth (referred to as "chilling verity") that strikes as the dreaded light appears. This is the moment associated with death, but is suddenly over and the speaker finds that his expectations weren't altogether fulfilled: "Yes, I was dead, and in the dreadful dawn [la terrible aurore]/ Was wrapped. - And what! That's all there is to tell? / The screen was raised, and I was waiting still". It should be noted that what the original says, more literally, is "I was dead without any surprise, and the terrible 'aurore' was enveloping me.” 22 In this manner, the poem appears to draw on the intimate association between photography and light, especially sunlight, in the early days of photography.

In light of the dedication to Nadar and the popular beliefs about photography, the poem appears to be about a photographic session. We may thus read it as a poem about surviving the experience of having one's photograph taken, emphasizing the thrill of the moment and the unfulfilled expectations, perhaps a mixture of disappointment and relief. It mocks all the superstitious ideas about photography, as well as the vain expectations of the bourgeois model having his picture taken. It probably also mocks the poetic association of photography, death and the sublime. The poem profits from all these ideas and reveals the truth of photography: It is a staged event associated with many expectations, but the experience as such is finally inconsequential. Nothing much appears to happen, in spite of the intense light.

Yet in retrospect, it seems clear that "nothing much" is actually quite a lot. What Baudelaire succeeds in capturing in this poem is a new and uncanny experience: the unsettling waiting in front of the camera, which creates a specific attention and self-awareness in the subject. It involves a strange passivity that recalls the situation of the spectator before a play. Still, this is not at all about seeing, but about being seen, and being seen is an event that appears to be inconsequential, but involves processes of subjectivation. The experience of being seen by an apparatus is especially disturbing, because, as Benjamin has stressed, the camera does not return one's gaze. At the critical moment, one's gaze is in fact blinded by the flashing light. In Baudelaire's poem, the speaker is enveloped by light, which implies that his sense of a distinct self is momentarily erased. 
We may thus see Baudelaire's poem as describing a new and uncanny experience: being photographed is here staged as an experiment on subjectivity; being photographed is staged as an experience of momentary death.

Baudelaire thus exploits the popular ideas about having one's photograph taken, romanticizes them considerably and combines them with a flash-like aesthetics and temporality. The search and expectation for truth, which is typically associated with a lifetime of strivings, is here condensed into a short interval and compared with the expectation of a theatre spectator. Yet the illuminating moment appears to bring only light, and no truth. Having one's photograph taken thus proves to be an utterly profane experience; it is an illumination without truth, quivering for a moment between the sublime and the banal, leaving the sitter puzzled.

\section{VISITING CARDS, MULTIPLICATION AND IDENTITY}

Baudelaire's attack on photographic technology in Salon de 1859 had referred to Daguerre as the "messiah of the crowd," but in 1859 the expensive technique of the daguerreotype (based on costly individual prints on silver plates) was already outdated and a new format had triumphed: the carte-de-visite, or the visiting card. According to the Encyclopedia of Nineteenth-Century Photography, "a rage for cards" caught on in France in 1858 and the carte-de-visite became "the latest social fashion": Baudelaire was of course familiar with the phenomenon; one of the photographs of him taken by Nadar - from a sitting in 1862 - was a carte-de-visite. ${ }^{23}$ Thus, Baudelaire may well have had this fashion in mind when he complained about the vain crowd's taste for images.

The carte-de-visite was patented in 1854 by André AdolpheEugène Disderi, and the key to this success was his technique: it allowed eight images to be exposed on one plate and thus reduced the cost considerably:

The carte-de-visite was one of the most popular photographic formats of the nineteenth century. It consisted of small portrait photograph, around $9 \mathrm{~cm}$ by $6 \mathrm{~cm}$, pasted onto a slightly larger piece of card. Cartes-de-visites derived their name from the fact that their size gave them the appearance of a visiting card, a purpose for which it was rarely, if ever, used. The advent of the carte-de-visite in the late 1850s was keyed into photography becoming a public and a commercial media. ${ }^{24}$ 
In the carte-de-visite, photography had found a standardized format, a size and a weight that made it easy to circulate, and a price that made it accessible to almost anyone.

The possibilities offered by new techniques and formats were explored from early on within the genre of portrait photography, and as Steffen Siegel has showed, this exploration also had a playful side. Common exercises in this period were the creation of photographic doubles and the multiplication of subjects. ${ }^{25}$ For instance, a popular form of photographic display was a frame with several windows, which distributed a series of photographic portraits of the same person in a circle. Through this optical device, a person was "split" into a specter of personalities. In this manner, identity was turned into a game.

The craze of visiting cards and the popular play with photographic doubles marked the visual culture in which Baudelaire lived. In this light, his exploration of multiplication and doubles becomes particularly interesting. From early on, photography was seen as an objective means of representing identity, serving both the bourgeois desire for self-representation (and later governmental need for the identification of citizens). However, Baudelaire rejected the bourgeois conception of identity, celebrating instead multitude, multiplication and a transgression of the "self." The prose poem “The Generous Gambler” ("Le Joueur généreux,” 1864) is particularly intriguing in this respect, because it relates the topic of the identity and multiplication to the visiting card. The principle of reproduction there becomes a means of subverting authenticity and identity, and it is associated with freedom and liberation from the original.

The prose poem is about a game with the devil in which the poetic subject plays and loses his soul. As with many of Baudelaire's other prose poems, it begins on the street, where the speaker of the poem suddenly encounters the devil. He follows him to splendid subterranean residence, where he is engaged in a devilish game, presumably a card game. The stake is nothing less than his soul, and as we may expect, the devil wins the game. However, the speaker does not seem to mind the loss of his soul and he claims that losing his soul amounts to the same as losing his visiting card on the street: "The soul is so impalpable, so often useless, and sometimes such a nuisance, that I felt no more emotion on losing it than if, on a stroll, I had mislaid my visiting card.” 26

In this comment, we first notice that the soul is a dispensable object for the speaker. By comparing it to a visiting card, he aligns it with a fixed identity, and an identity that is extrinsic rather than 
intrinsic. In this manner, Baudelaire could be seen as emptying out the subject, depriving his protagonist both of his inner spirituality (a soul) and a (socially) fixed identity (a visiting card), and claiming that these two amount to the same (worthless) thing. Also in play here is the ambiguous logic of the visiting card; although the visiting card is, in theory, a device for arresting identity and, as it were, capturing the soul (or an identity) in an image, it paradoxically also embodies the capacity of the soul (or an identity) to visit, travel, and circulate, and thus to escape arrest. The very point of visiting cards is to produce a large number of copies and disperse them widely. However, with the spread of copies, the idea of an original is weakened, and in the prose poem, the original actually proves to be dispensable. Why bother with the mysteries of the soul, when your identity can easily be reproduced - and put into circulation by means of visiting cards?

What Baudelaire describes in this prose poem is thus a mysterious "traffic in souls." 27 First, there is the devil trading in souls, second, there is the producer of visiting cards trading in images, and third, there is the speaker of the poem, taking leave of his soul, just as he would have taken leave of his visiting card, allowing it to travel, visit and escape arrest. We may thus ask if the speaker of the poem is here playing a game of identities, whereas the old fashioned devil is merely playing for a soul. It may indeed seem as if the poor devil is hopelessly committed to the original, whereas the speaker - having entered the era of technological reproducibility has managed to escape his grasp. ${ }^{28}$

A process of multiplication also takes place in the sonnet "The seven old men" ("Les sept vieillards"), and once more, the scene is the streets of Paris. The poem was published in the second version of The Flowers of Evil, in the section entitled "Parisian scenes." This time the dissolution of identity does not concern the speaker of the poem; it concerns a man who suddenly appears before him. As if by magic, he is multiplied into seven men. The poem, which consists of 21 strophes, begins by hailing Paris as a "city full of dreams" and by describing the Parisian streets in terms of the theater (using words such as "simulate" and "stage-set"). ${ }^{29}$ Then the event is narrated as a haunting vision: A poor old man suddenly appears before the speaker, and then his double, and successively seven identical, old men appear out of nowhere: 
Then an old man whose yellow rags

Were imitations of the rainy sky

[...]

Appeared quite suddenly to me. I'd say

His eye was steeped in gall; his glance was sharp

[...]

His double followed; beard, eye, back, stick, rags,

No separate traits, and come from the same hell

This second ancient man, baroque, grotesque,

Trod with the same step towards their unknown goal

To what conspiracy was I exposed,

What wicked chance humiliated me?

For one by one I counted seven times

Multiples of this sinister old man!" 30

It is crucial that this vision is associated with death. The old men appear to come "from the same hell", but in the next strophe, they are seen as eternal: "These monsters smacked of all eternity!" Further, the speaker envisions his own death at the sight of one more replica, which would have be the eight one: "Could I still live and look upon the eight[?]" It may be pointed out that eight is the number of prints on a set of visiting cards, so the number may have given associations in that direction in Baudelaire's day, but this is of course uncertain. It is interesting, however, that these men appear to have no origin; they appear out of nowhere, or from the same hell, yet their appearance make them seem eternal. The appearance of these identical men with highly uncertain existences is described as "mysterious," "absurd," and as a "conspiracy."

The poem closes with the speaker turning his back on the parade of men, feeling bedazzled as a drunk "seeing double." Multiplication thus appears to have an intoxicating effect and certainly undermines the concept of bourgeois identity. Returning home, he fails to come to terms with the event through the application of reason, yet his soul is described as dancing:

- I turned my back on this parade from Hell

Bedazzled like a double-visioned drunk

I staggered home and shut the door, aghast, [...]

And my soul danced in circles like a hull

Dismasted, on a monstrous shoreless sea 
The soul dancing in circles on a shoreless sea is clearly an image of liberation. It appears that the vision of the old man and his doubles - the seven (possibly eight) multiples of the old man - has in some way liberated the speaker from previous constraints: the soul is freed of its body and gives itself up to a circular movement. In the original, the verb "dancing" is repeated once [mon âme dansait, dansait], and the repetition may give an even stronger feeling of liberation. Yet it may also create ambivalence with respect to the relation between true freedom and repetition.

At the time when Baudelaire wrote this poem, romantic poetry had already explored the figures of the doppelgänger and the ghost. However, Baudelaire takes this several steps further when he describes a process of multiplication that leads to seven, perhaps eight, identical men. Further, he does not make them appear at a secluded castle after dark, but in a Parisian street in plain daylight. Baudelaire's first title for the poem was in fact "Fantômes parisiens.” If Baudelaire's treatment of this topic differs from a romantic treatment, one of the reasons for this may be the emergence of a new visual culture marked by the popularity of portrait photography (especially visiting cards), the circulation of copies, and popular play with photographic doubles and "split personalities.” It seems very likely that Baudelaire's poetic play with doubles and multiplication, as well as his liquidation of the concept of bourgeois idea of identity, was indebted to this culture, and that his love of commonplaces included the commonplaces and clichés of photography.

\section{PLAYING WITH $19^{\text {TH-CENTURY MEDIA DISPOSITIVES }}$}

The question of how we today should assess Baudelaire's relation to photography is important, and the theoretical framework we apply when we discuss it, matters. Benjamin's analysis of the profound cultural changes that took place in Baudelaire's day remains invaluable; yet, even if he displays a deep understanding of Baudelaire, he does not offer much detailed analysis of his writings, and he depicts him mostly as a troubled poet fighting the new media. Following Benjamin, many readers have simply dismissed Baudelaire's views on photography as reactionary and considered it part of his defense of "pure" art. Yet, several critics have contributed to a more nuanced picture. ${ }^{31}$ My own contention that Baudelaire played with the media dispositives of his day may hopefully also contribute to seeing his writings and his aesthetics in a somewhat different light.

Using a framework that differs slightly from Benjamin's, but is also deeply indebted to it, I wish to bring attention to the way 
Baudelaire responded to these new technologies. For if the media technology is at the outset part of a commercial and technological enterprise (emerging in the period of "high capitalism," to use Benjamin's expression), it also has another potential that should be acknowledged: a potential for play. This is, as we might expect, a potential that may be explored by poets and artists, and it could be argued that the possibilities for play in art increase in the era of technological reproducibility.

In a rarely quoted passage in "The Work of Art in the Age of its Technological Reproducibility,” Benjamin in fact acknowledges that the shattering of the aura entails an increased potential for play: "[W]hat is lost in the withering of semblance and the decay of the aura in works of art is matched by a huge gain in the scope for play [Spiel-Raum]." ${ }^{32} \mathrm{He}$ is referring specifically to the possibilities of film, which, because it is based on the principle of montage, lends itself to infinite forms of play. However, Benjamin's interest in the category of play was not restricted to film. As Miriam Bratu Hansen has showed, the term Spiel was central to Benjamin's cinema aesthetics, but it also played a significant role in his aesthetics generally. ${ }^{33}$ The new possibilities opened up in the era of technological reproducibility entail that artworks are no longer treated as icons and fetishes, but instead lend themselves to free play. With Benjamin's perspectives on film in mind, we may thus assert that the age of technical reproduction actually increases the scope of play in art.

This is also a topic that has been addressed by Agamben, who asserts that the workings of the dispositives may be countered by profanation and play. However, for Agamben the advanced stage of capitalism we live in today represents a serious challenge. As he sees it, capitalist society has captured the dispositives (notably language and images) and withdrawn them from "free use." Just as religion confines certain things and practices in a holy sphere that is inaccessible to humans, capitalism lays claim to certain things and practices, captures them within a certain logic and, in this manner, precludes their free use. In this sense, capitalism could be described as a "massive accumulation and proliferation" of dispositives. ${ }^{34}$

What is required in this situation, Agamben argues, is a recuperation of the dispositives through a process of profanation. It is in this context that he discusses the potential of play, seeing it as an organ of profanation. Yet, Agamben contends that capitalism today has made profanation a difficult enterprise because it has extended its reach to include all spheres of society and captured all the means of profanation - without remainder. 
Play as an organ of profanation is in decline everywhere. Modern man proves he no longer knows how to play precisely through the vertiginous proliferation of new and old games [...] In this sense, televised game shows are part of a new liturgy [...] To return play to its purely profane vocation is a political task.” 35

Agamben's critical perspectives are important today, when the era of technological reproducibilty has given way to the era of advanced, digital media technology. Yet, it is also essential to remember that the course of media history is not a one-way street without disruptive moments. In this regard, it is worth reconsidering $19^{\text {th }}$-century media culture and the possibilities for play that came with the first phase of modernity. It is no wonder that both Benjamin and Agamben are keen readers of Baudelaire, for he appears to have understood these processes very well. His attitude towards the new media culture remained ambiguous; he fought against its most vulgar installments, but was also enchanted by its imaginary potential. Baudelaire thus entertained a double consciousness with respect to $19^{\text {th }}$-century media culture; in his poetry, he played with its clichés and showed that that their spell could be broken. 
1 Walter Benjamin, The Writer of Modern Life: Essays on Charles Baudelaire, ed. Michael W. Jennings, trans. Howard Eiland et.al. (Cambridge: The Belknap Press, 2006); Walter Benjamin, The Arcades Project, trans Howard Eiland and Kevin McLaughlin (Cambridge: The Belknap Press, 1999); David Harvey, Paris: Capital of Modernity (New York: Routledge, 2003).

2 Charles Baudelaire, Selected Writings on Art and Literature, trans. P. E. Charvet (London: Penguin Books, 1972), 157. "Avec une plume tout cela est pâle et glacé.» Charles Baudelaire, CEuvres complètes 2 (Paris: Gallimard, 1976), 540.

3 Baudelaire, Selected Writings, 412. «En vérité, il est difficile à la simple plume de traduire ce poème fait de mille croquis.» Baudelaire, QEuvres complètes 2, 702.

4 Baudelaire, Selected Writings, 434-435. "[Il est] très difficile à sténographier Baudelaire, CEuvres complètes 2,724 .

5 Jean-Louis Baudry, "Effets idéologiques produits par l'apparail de base," in Cinéthique 7-8 (1970): 1-8 and "Le dispositif: approches métapsychologiques de l'impression de réalité," in Communications 23 (1975): 56-72. Both articles can be found in Jean-Louis Baudry, L'Effet cinéma (Paris: Editions Albatros, 1978). Michel Foucault, The History of Sexuality 1, trans. Robert Hurley (New York: Vintage Books, 1990).

6 Giorgio Agamben, What is an Apparatus? and Other Essays, trans. David Kishik and Stefan Pedatella (Stanford, Cal.: Stanford UP, 2009), 14.

7 English translations of both Foucault and Agamben use the word apparatus for the French word dispositif and for the Italian word dispositivo. In my opinion, this is unfortunate because apparatus suggests something that is too concrete, like a mechanism or a machine. Although the French word dispositif and the Italian word dispositivo obviously have these denotations, they also have more abstract denotations, like arrangement, disposition, system, law and decree. These significations are especially important in Agamben's extended use of the concept, and they must be appreciated to understand how Agamben's use is different from Foucault's. To maintain this wide range of significations, I will generally use the original term dispositive, which today is more and more used in English in academic contexts relative to Foucault and Agamben. For a discussion of the English translation of this term, see Jean Bussolini, "What is a dispositive?" Foucault Studies 10 (2010): 85-107. Bussolini argues that "dispositive" is a better translation than "apparatus."

8 For an introduction to the study of intermediality, see Joachim Paech and Jens Schröter, eds, Intermedialität analog/digital. Theorien - Methoden - Analysen (München: Fink, 2008).

9 Jay David Bolter and Richard Grusin, Remediation: Understanding New Media (Cambridge, Mass: 2000).

10 Marit Grøtta, Baudelaire's Media Aesthetics: The Gaze of the Flâneur and $19^{\text {th }}$-Century Media (New York: Bloomsbury, 2015).

11 Baudelaire, Selected Writings, 285.
12 Jonathan Culler, "Poésie et cliché chez Baudelaire," in Le Cliché, ed. Gilles Mathis (Toulouse: Presses Universitaires du Mirail, 1998), 215.

13 Maxime du Camp, Chants modernes (Paris: Michel Lévy Frères, 1855).

14 Champfleury, Le Réalisme (Paris: Michel-Lévy Frères, 1857), 91-93.

15 Baudelaire, Selected Writings, 295; Baudelaire, CEuvres complètes 2, 616.

16 Baudelaire, Selected Writings, 297; Baudelaire, QEuvres complètes 2, 618.

17 Nadar wrote about his carrier as a photographer in a book published in 1900, see Nadar, Quand j'étais photographe (Paris Editions d'aujourd'hui, 1979). He also published a biographical book on Baudelaire, Nadar, Charles Baudelaire intime: Documents, notes et anecdotes (Sens: Obsidiane, 1990).

18 Nadar, Quand j'étais photographe, 6.

19 Champfleury [Jules François Félix Fleury-Husson], "The Legend of the Daguerreotypist," in Literature \& Photography: Interactions 1840-1990, ed. Jane Rabb (Albuquerque: University of New Mexico Press, 1995), 14.

20 Jérôme Thélot and Dana MacFarlane have also analyzed the poem as a comment on photography, stressing the close connection between photography, death, and sudden illumination. Jérôme Thélot, Les Inventions littéraires de la photographie (Paris: Presses Universitaires de France, 2003), Ch. 2; Dana MacFarlane, “'Waiting Still:' Baudelaire and the Temporality of the Photographic Portrait," History of Photography 36 (2012): 3-14.

21 Charles Baudelaire, The Flowers of Evil, trans. James McGowan (Oxford: Oxford University Press, 1998), 281.

22 "Connais-tu, comme moi, la douleur savoreuse, / Et de toi fais-tu dire: 'Oh! l'homme singulier!' / - J'allais mourir. C'était dans mon âme amoreuse, / Désir mêlé d'horreur, un mal particulier; // Angoisse et vif espoir, sans humeur factieuse. / Plus allait se vidant le fatal sablier, / Plus ma torture était âpre et délicieuse; / Tout mon cœur s'arrachait au monde familier. // J'était comme l'enfant avide du spectacle, / Haïssant le rideau comme on hait un obstacle....// J'étais mort sans surprise, et la terrible aurore / M'enveloppait. - Eh, quoi! n'est-ce donc que cela? / La toile était levée, et j'attendait encore.» Charles Baudelaire, QEuvres complètes 1 (Paris: Gallimard, 1975), 128-29.

23 Dana MacFarlane, "'Waiting Still'," 5.

24 John Hannavy, ed., Encyclopedia of Nineteenth-Century Photography, Vol. 1, (London: Routledge 2008), 276.

25 Steffen Siegel, "Der Multiplizierte Fotograf: Figuren den jüngeren Bildgeschichte," in Charles Nègre: Selbstporträt im Hexenspiegel. Edited by Michael Hagner, Bernd Stiegler and Felix Thürlemann (Paderborn: Fink Verlag, 2014), 88-101.

26 Charles Baudelaire, The Prose Poems and Fanfarlo, trans. Rosemary Lloyd (Oxford: Oxford University Press, 1991), 75. "L'âme est une chose si impalpable, si souvent inutile et quelquefois si gênante, que je n'éprouvai, quant à cette perte, qu'un peu moins d'emotion que si j'avais égaré, dans une promenade, ma carte de visite." Baudelaire, CEuvres complètes 1, 326. 
27 Traffic in Souls is the title of a feature film from 1913, an urban thriller on women forced into prostitution. Tom Gunning discusses the film in an illuminating essay on urban spectatorship, where he claims that "the view of the city that emerges from this film brings us to the final aporia of the urban spectator, unable to trust or evaluate all she sees." Although the term "traffic in souls" here has a more concrete signification (white slavery), the issues Gunning discusses are related to the issues discussed in this chapter. See Tom Gunning, "From Kaleidoscope to the X-Ray: Urban Spectatorship, Poe, Benjamin, and Traffic in Souls (1913)," Wide Angle 19 (1997): 41.

28 I have published a thorough analysis of this prose poem in Grøtta, Baudelaire's Media Aesthetics, 66-69.

29 Baudelaire, The Flowers of Evil, 177-80.

30 «Tout à coup, un vieillard dont les guenilles jaunes / Imitaient la couleur de ce ciel pluvieux, / [...] M'apparut. On eût dit sa prunelle trempée / Dans le fiel; son regard aiguisait le frimas [...]// Son pareil le suvait. Barbe, œil, dos, bâton, loques, / Nul trait ne distinguait, du même enfer venu / Ce jumeau centenaire, et ces spectres baroques / Marchaient du même pas vers un but inconnu. // À quel complot infâme était-je donc en butte, / Ou quel méchant hasard ainsi m'humiliait? / Car je comptai sept fois, de minute en minute, / Ce sinistre vieillard qui se multipliait ! // Que celui-là qui rit de mon inquiétude / Et qui n'est pas saisi d'un frisson fraternel / Songe bien que malgré tant de décrépitude / Ces sept monstres hideux avaient l'air éternel ! // Aurais-je, sans mourir, contemplé le huitième [?]/[...] - Mais je tournai le dos au cortège infernal. // Exaspéré comme un ivrogne qui voit double, / Je rentrai, je fermai ma porte, épouvanté, // [...] Et mon âme dansait, dansait, vieille gabarre / Sans mâts, sur une mer monstrueuse et sans bords!» Baudelaire, CEuvres complètes 1, 87-88.

31 In addition to Thélot, Les Inventions littéraires and MacFarlane, "Waiting Still", I would like to mention the following contributions: Susan Blood, "The Sonnet as Snapshot: Seizing the Instant in Baudelaire's 'A une passante'," Nineteenth-Century French Studies 36 (2008): 255-269; Françoise Meltzer, Seeing Double: Baudelaire's Modernity (Chicago: University of Chicago Press, 2011); Antoine Compagnon, Baudelaire: L'Irréductible (Paris: Flammarion, 2014); and Timothy Raser, Baudelaire and Photography: Finding the Painter of Modern Life (Cambridge: Modern Humanities Research Association, 2015).

32 Walter Benjamin, The Work of Art in the Age of its Technological Reproducibility and Other Writings on the Media, ed. Michael Jennings, Brigid Doherty, and Thomas Y. Levin (Cambridge, Mass.: The Belknap Press, 2008), 49.

33 Miriam Bratu Hansen, "Room-for-Play: Benjamin's Gamble with Cinema," October 109 (2004): 3-45. Hansen brings attention to Adorno's resistance to Benjamin's "aesthetics of play"; for Adorno, play was a degradation of art to a form of sport, complying with the culture industry.

34 Agamben, What is an Apparatus?, 15.

35 Giorgio Agamben, Profanations, trans. Jeff Fort (Zone Books, 2007), 76. 